\title{
Allium olivieri Boiss. (Alliaceae), a new taxon to Turkey, with contributions to its taxonomy
}

\author{
İsmail Eker ${ }^{1 *}$, Mehmet Koyuncu² \\ 'Department of Biology, Abant Izzet Baysal University, Gölköy, 14280 Bolu, Turkey \\ ${ }^{2}$ Department of Pharmaceutic Botany, Ankara University, Tandoğan, 06100 Ankara, Turkey
}

\section{Abstract}

Allium olivieri Boiss. (Alliaceae) is reported as a new record for Turkish flora. It was identified using the collected specimens and Flora orientalis, Flora of Iraq and Flora Iranica. The detailed description, illustrations, geographical distribution, habitat, status of IUCN extinction risk and some comments and discussions on the taxonomy of the species are given.

Keywords: Alliaceae, Allium, Allium olivieri, Turkey

\section{Introduction}

The genus Allium L. was revised by Kollmann [1] for the "Flora of Turkey and East Aegean Islands" in which 141 species (161 taxa) were recognized. After this study, 26 further new species (26 taxa) have been described from Turkey in the last twenty years [2-6]. Thus, the total number of Allium species has increased to 167 (187 taxa). In this paper, we provide a new record in Turkey for Allium olivieri Boiss. The total number of Allium species recorded in Turkey has now increased to 168 (188 taxa).

During a field work in the Tektek mountain, Şanliurfa, South East of Turkey, $50 \mathrm{~km}$ away from the border of Syria, Eker collected a number of interesting Allium specimens. Among them were specimens which could not be identified using the account in the Flora of Turkey [1-3]. However, using Flora Orientalis [7], Flora Iranica [8], and Flora of Iraq [9], the specimens were identified as Allium olivieri Boiss. This is a new record for the Flora of Turkey. The record is not surprising since this species also grows in nearby Iran and Iraq.

\section{Results}

\section{Plant Description}

The following description is mainly based on our own

\footnotetext{
* Corresponding author. Email: ekerismail@mynet.com
}

This is an Open Access digital version of the article distributed under the terms of the Creative Commons Attribution 3.0 License (creativecommons.org/licenses/by/3.0/), which permits redistribution, commercial and non-commercial, provided that the article is properly cited. observations, verifying those given by Boissier [7] and Wendelbo $[8,9]$ and adding some lacking features.

Allium olivieri Boiss. [7] (Fig. 1, Fig. 2, Fig. 3). Syn.: A. schubertii (non Zucc.) Feinbrun; A. stenopetalum (non Boiss. et Ky.) Feinbrun [10]. Typus: Hab. in Mesopotamia inter Mossul et Baghdad, Olivier, G.

Bulb 2-2.5(-3.5) × 2-2.5(-3.5) cm diam., ovoid to globose-ovoid; outer tunics with a short neck, brownish-grey, thin, cracking and more or less splitting into fibres. Scape 10-20 cm $\times 3-5 \mathrm{~mm}$ diam., thick, during anthesis comparatively thin and flexuose, in fruit stout and strict, finely ribbed. Leaves 2-6, overtopping or not exceeding the inflorescence, the broadest one $0.7-2.1 \mathrm{~cm}$, all basal, apex cucullate, margin finely scabrid. Spathe $2-3.5 \mathrm{~cm}, 1 / 2$ to $1 / 4$ the length of the umbel, 1-5-lobed, often enclosing the base of the pedicels, tinted purplish, persistent. Umbel many-flowered, comparatively dense, fasciculate to hemispherical. Pedicels unequal, $2-9 \mathrm{~cm}$ long, thickened below the flowers, ebracteolate. Perianth purplish, pinkish to pinkish-white. Tepals 5-7 × 1-1.5 mm diam., narrowly oblong-elliptic to lanceolate, obtuse to acuminate, soon becoming reflexed. Filaments 5-6 $\mathrm{mm}$ long, narrowed from a broad base, connate and adnate to the tepals at the base, erect; anthers 1.5-2.5 mm long, oblong, purplish-red at fresh becoming purplish-black after pollination; pollen yellow. Ovary provided with six small horns at the apex. Capsule 3-5 $\times 4-6 \mathrm{~mm}$ diam., with 6 well-developed divergent horns at the apex, each locule one-seeded; seed 2.5-3 × 2-2.5 mm diam., black, rugose, triangular with two rounded angles to orbicular. HABITAT. In fields on steppic hills and plains, on sandy clay and silty soils. ALTITUDE. 600-700 $\mathrm{m}$ in Turkey. PHENOLOGY. Flowering in March-April, Fruiting April-May. DISTRIBUTION. SE Anatolia, Syria, Iraq, SW Iran. PHYTOGEOGRAPHIC REGION. Irano-Turanian element.

Specimens examined: (Turkey) C7 Şanlıurfa: Tektek mountains, between Karakuş-Başaklı villages, in fields, $670 \mathrm{~m}$, 2007.04.06, Eker 1776; north of Karakuş village, in fields, 


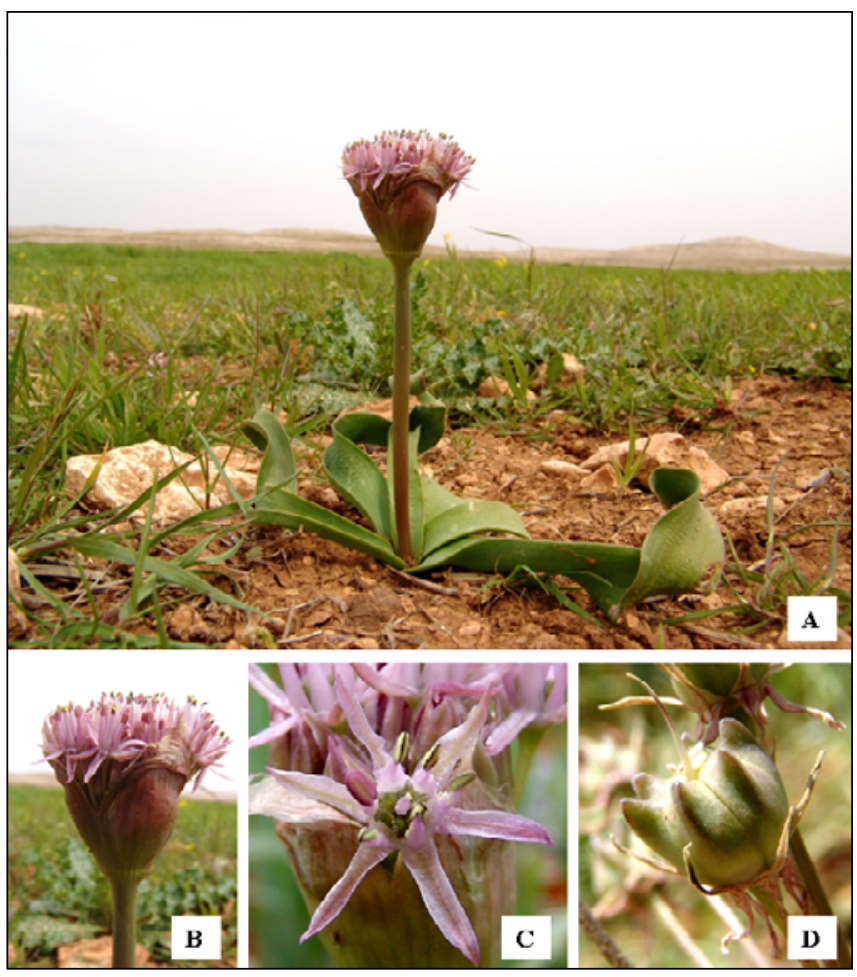

Fig. 1 Allium olivieri Boiss. a General view in the natural habitat. b Inflorescence. c Flower. d Fruit. Photo by Eker, 2007.04.06 and 2009.04.23.

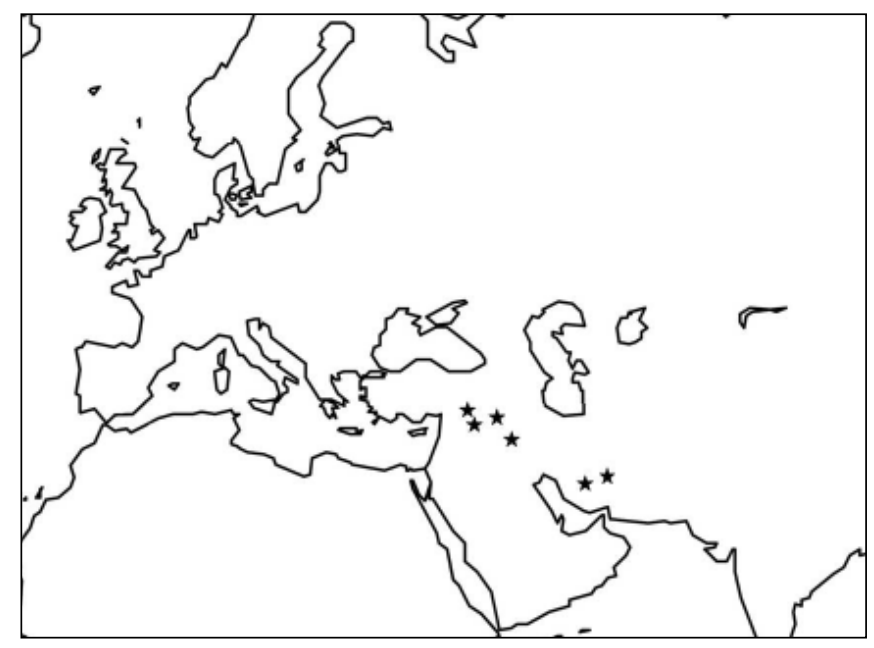

Fig. 2 Geographical distribution of Allium olivieri Boiss. in the world.

631 m, N 370 01.106, E 0390 14.475, 2009.04.23, Eker 2272.

\section{Key to closely related Allium species in Turkey}

1. Ovary and capsule provided with 6 apical horns; tepals soon becoming reflexed and often contorted - A. olivieri.

1. Ovary and capsule without 6 apical horns; tepals erect after anthesis:

2. Perianth segments $9-14 \mathrm{~mm}$; leaves as long as a stem or longer, 8-15 mm broad; fruiting pedicels $6-7 \mathrm{~cm}$, unequal - A. nоёanum.

2. Perianth segments $7-9 \mathrm{~mm}$; leaves shorter than stem, 3-8 mm broad; fruiting pedicels less than $6 \mathrm{~cm}$, equal $-A$. shatakiense.

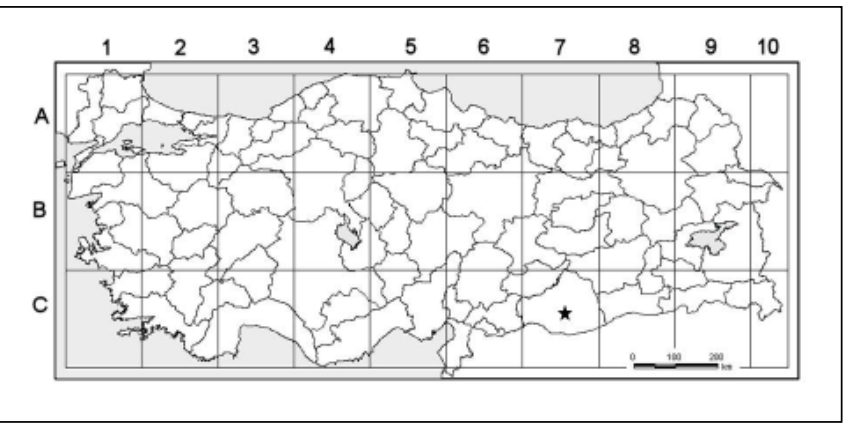

Fig. 3 Geographical distribution of Allium olivieri Boiss. in Turkey.

\section{Conservation status}

Allium olivieri has a very limited distribution in South East Anatolia at national level. The natural distribution area of the species is damaged due to cultivation and grazing activities, and is also being continuously destroyed by the construction of tunnels for the irrigation of plains. Thus, the habitat of $A$. olivieri in Turkey is under threat and its destruction would lead to a dramatic decrease of the abundance or even complete extinction of this species. Nevertheless, it grows at the other localities in neighbouring countries Iraq, Iran and Syria. Taking into account all these points, the species should be classified as "Vulnerable" (VU) [11] and both it and the site in Turkey should be protected.

\section{Discussion}

Allium olivieri had not been recorded in Turkey before this work. A supplemented description based on individuals from the discovered population compared with the original description in the "Flora Orientalis" is given. A comparison of selected characters between our findings with Flora Orientalis [7], Flora Iranica [8], and Flora of Iraq [9] is given in Tab. 1. It is apparent from this comparison that the specimens from Turkey show differences such as number of spatha lobes, pedicel length, and perianth colour from those found in Iran and Iraq. It is likely that the variation in spatha lobes, pedicel and scape length, and perianth colour observed in A. olivieri reflects a variation in habitat and ecological conditions. As can be seen from the table, some morphological characters of this species were not given in Flora Orientalis, Flora Iranica, and Flora of Iraq such as: spatha length, tepal width, anther and pollen colour, capsule width, and all of seed features. Also, the approximate values belonging to morphological characters that given in abovementioned floras have been enhanced. Moreover, it is a little known species in literature and the photos of the plant are very likely presented here for the first time.

Morphologically, although A. olivieri resembles A. noëanum Reuter ex Regel and $A$. shatakiense Rech. fil. from the same section, it is a very interesting and distinctive species differing from the both species and the other Allium species by having ovary and capsule with six apical horns. In addition, it differs from $A$. noёanum by having smaller and reflexed perianth segments, and from $A$. shatakiense by having longer and unequal pedicels, longer spathe, bigger bulb, shorter and reflexed perianth segments.

A. olivieri has very strong scent, beautiful flowers and habit. For this reson, it may have medicinal and/or ornamental potential. In this purposes, the bulbs of the plant were taken 
Tab. 1 A comparison of selected morphological characters of Allium olivieri between descriptions given in the Flora Orientalis, Flora Iranica, Flora of Iraq, and in the present study.

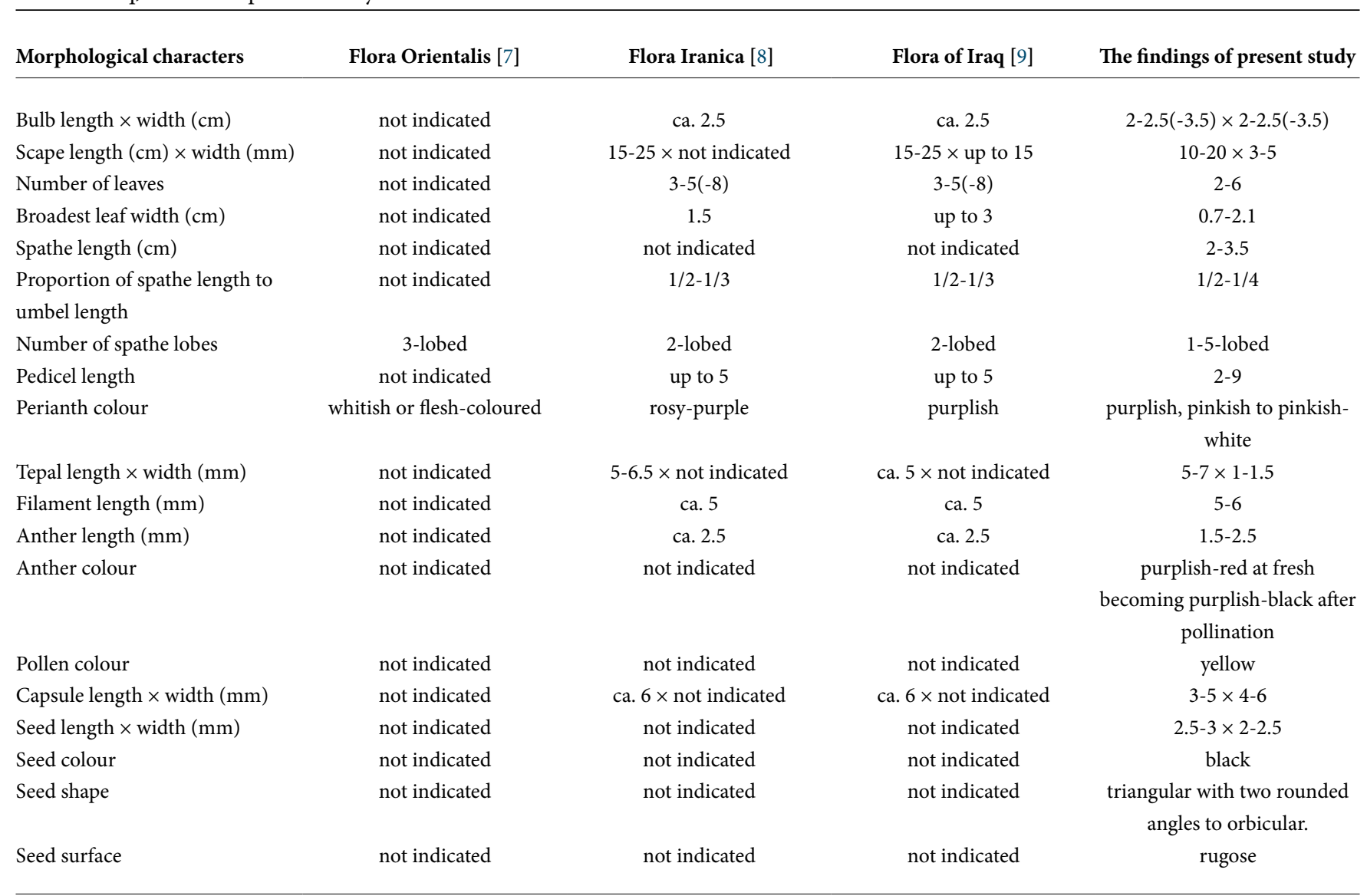

for cultivation in Abant Izzet Baysal University for ex-situ conservation and further studies.

\section{References}

1. Kollmann F. Allium L. In: Davis P, editor. Flora of Turkey and the East Aegean Islands. Edinburgh: Edinburgh University Press; 1984. p. 98-211. (vol 8).

2. Davis P, editor. Flora of Turkey and the East Aegean Islands. Edinburgh: Edinburgh University Press; 1988.

3. Özhatay N, Tzanoudakis D. Allium L. In: Güner A, Özhatay N, Ekim T, Başer K, editors. Flora of Turkey and the East Aegean Islands. Edinburgh: Edinburgh University Press; 2000. p. 224-232. (vol 11).

4. Deniz I, Sümbül H. Allium elmaliense (Alliaceae), a new species from SW Anatolia, Turkey. Ann Bot Fennici. 2004;41(2):147-150.

5. Demirelma H, Uysal T. Allium ertugrulii sp. nov. (Alliaceae) from southern Turkey. Nord J Bot. 2007;25(5-6):315-317. http://dx.doi.org/10.1111/j.0107-055X.2008.00132.x

6. Dural H, Bağci Y, Ertuğrul K. Allium yildirimlii (Alliaceae), a new species from South Anatolia, Turkey. Ot Sist Bot Derg. 2009;16:1-8.

7. Boissier E. Flora orientalis. Geneva: Lugduni; 1882. (vol 5).

8. Wendelbo P. Allium L. In: Rechinger K, editor. Flora Iranica. Graz: Akademische Druck- u. Verlagsanstalt; 1971. p. 3-96. (vol 76).

9. Wendelbo P. Allium L. In: Townsend C, Evan G, Al-Rawi A, editors. Flora of Iraq. Baghdad: Ministry of Agriculture and Agrarian Reform Press; 1985. p. 137-177. (vol 8).

10. Feinbrun N. Further studies on Allium of Palestine and the neighbouring countries. Palestine J Bot Jerusalem Ser. 1948;4:144-157.

11. IUCN [Internet]. IUCN Red List Categories and Criteria version 3.1. 2010 [cited 2010 May 20]; Available from: http://www.iucnredlist.org/technical-documents/ categories-and-criteria/2001-categories-criteria 